Egyptian Journal of Aquatic Biology \& Fisheries

Zoology Department, Faculty of Science,

Ain Shams University, Cairo, Egypt.

ISSN $1110-6131$

Vol. 23(2): 317-330 (2019)

www.ejabf.journals.ekb.eg

\title{
Mesozooplankton of the Damietta Branch, River Nile, Egypt.
}

\section{Wael S. El-Tohamy* and Samar N. Abdel-Baki}

Zoology Department, Faculty of Science, Damietta University, New Damietta, Egypt *Corresponding author: waelsalah@du.edu.eg, Waeleltohamy5@gmail.com

\begin{abstract}
ARTICLE INFO
Article History:

Online: May 15, 2019

Keywords:

Mesozooplankton

River Nile

Damietta Branch

Diversity

Distribution

Eutrophication
\end{abstract}

Received: April 16, 2019

Accepted: May 9, 2019

\begin{abstract}
Mesozooplankton abundance and distribution at Damietta Branch, Nile River was studied to assess the impacts caused by human activities. The sampling was done monthly at seven stations during October 2013September 2014. A plankton ring net with $180 \mu \mathrm{m}$ mesh size was used to avoid the bias toward the collection of smaller mesozooplanktons such as rotifers and copepod larvae. Thirty-six mesozooplankton taxa were recorded. Cladocera was the most abundant group (41.6\%), followed by Copepods (29.9\%), Rotifera (14.8\%), and Ostracoda (13.2\%). The decrease in rotifers density in favor of copepods and cladocerans in the ROT:CLA:COP ratio suggesting an increase in the area eutrophication. According to SIMPER analysis, the most important taxa were Bosmina longirostris, Ceriodaphnia reticulate, Moina micrura, Acanthocyclops americanus, Brachionus calyciflorus, and Candona subgibba. Multivariate analysis indicated that the variations in species distribution were associated with environmental factors, especially water temperature, conductivity, and nitrate. The degree of anthropogenic disturbance determines the quality and quantity of plankton in the study area. Consequently, the discharged post-cooling waters should be controlled to protect zooplankton fauna and in consequence the planktivorous fish of the study area.
\end{abstract}

\section{INTRODUCTION}

Rivers and streams ecosystems are sensitive to many environmental stressors; human activities mainly responsible for most of these stressors (Sala et al., 2000). Streams in developing countries such as Egypt have suffered from severe environmental problems such as chemical and organic pollution, caused by runoff from agricultural chemicals, poorly managed industrial process, and the absence of suitable treatment of sewage and other urban wastes. The results may include the denaturation of water which is no longer sustain healthy ecosystems to aquatic organisms (Arthington et al., 2010). Although the well known adverse effect of pollution in many river systems (Pernet-Coudrier et al., 2012; Xiong et al., 2017; Zhang et al., 2017), it remains indistinct how variety and differences in environmental variables interact to determine community structure of living organisms in stressed river ecosystems in a narrow geographical range, especially for those the critical but poorly studied communities such as zooplankton. Such communities are highly sensitive to environmental fluctuations. The variations in 
zooplankton abundance and/or composition can be used as an significant sign of ecological changes or disturbance (Joseph and Yamakanamardi, 2011).

Nile River is one of the longest rivers of the world, flowing from south to north, covering the whole of Egypt between latitudes $21^{\circ} 55^{\prime}-31^{\circ} 17^{\prime} \mathrm{N}$. At El-Kanater El-Khyria (close to Cairo) the Nile bifurcates into two branches, namely; the Rosetta and Damietta branches. Ending dams were erected on both branches. The Damietta Branch is about $240 \mathrm{~km}$ long. The lower $21 \mathrm{~km}$ of the branch is cut-off from the river and remains freely connected to the sea. This is achieved by the open/closed dam (Faraskour dam), $3 \mathrm{~km}$ south to Damietta City. This dam is rarely opened and usually closed for most of the year to prevent invasion of the sea water into Damietta Branch. Although the great benefit of this dam which maintains the river water levels by controlling the flow between the Damietta Branch and Mediterranean Sea, the significant reduction in river flow accumulated the wastes and converting the river into a waste collecting system.

Zooplankton of freshwater rivers tends to be dominated by rotifers and bosminids; other cladocerans and copepods were relatively few (Bum and Pick, 1996; Mola and Ahmed, 2015; Rodríguez et al., 2013). Zooplankton are considered to be one of the essential players in the Nile River ecosystem, acting as a link between the first trophic level (primary producers or phytoplankton) and higher trophic levels including planktivorous fish (El-Otify and Iskaros, 2015; Rzoska, 1976)

In the Egyptian waters the widespread use of fine plankton nets $(55 \mu \mathrm{m}$ or even lower) has led to a comparatively low diversity and abundance of mesozooplankton (adult copepods and cladocerans), as the fine nets are clogged easily which allowing the mesozooplankton to escape during the filtration process (Buskey et al., 2002). As a result, most of the zooplankton samples collected previously in the Nile River using fine nets showed an overwhelming increase in diversity (richness and quantities) of small taxa over the larger species. As pointed out by Riccardi (2010), the coarse nets $(\approx 200 \mu \mathrm{m})$ is providing reliable descriptions of the mesozooplankton assemblages than that of the finer nets. Also, Hopcroft and other (1998) mentioned that the use of coarse nets $(180-300 \mu \mathrm{m})$ yields an adequate representation of the community structure and its dynamics. During the present study, we assumed that the used coarse net $(180 \mu \mathrm{m})$ should display a reliable description of the mesozooplankton assemblage and avoid the strong bias towards collecting of small animals in most freshwater zooplankton studies. The study was also aimed to examine of the mesozooplankton community of the Nile River Damietta Branch with three objectives. The first was to determine the composition, distribution, and abundance of mesozooplankton in the Damietta Branch through monthly sampling over a one-year round. The second objective was to analyze the impact of some physicochemical factors on community variations. The third was to clarify the relationship between species and their environment within the study area.

\section{MATERIALS AND METHODS}

\section{Study area and stations}

The study area (Fig. 1) extended about $78 \mathrm{~km}$ in Damietta Branch. The field data used in this paper were collected at seven stations every month from October 2013 to September 2014. Pollutants slightly stressed the station I was located at the water inlet of water planet station. Staions II and VI near the hot water outlet of thermal power generations plants. Station III near the drainage canal of inorganic 
fertilizer factory receiving industrial sewage. Stations IV, V, and VII near some villages receiving domestic sewage.

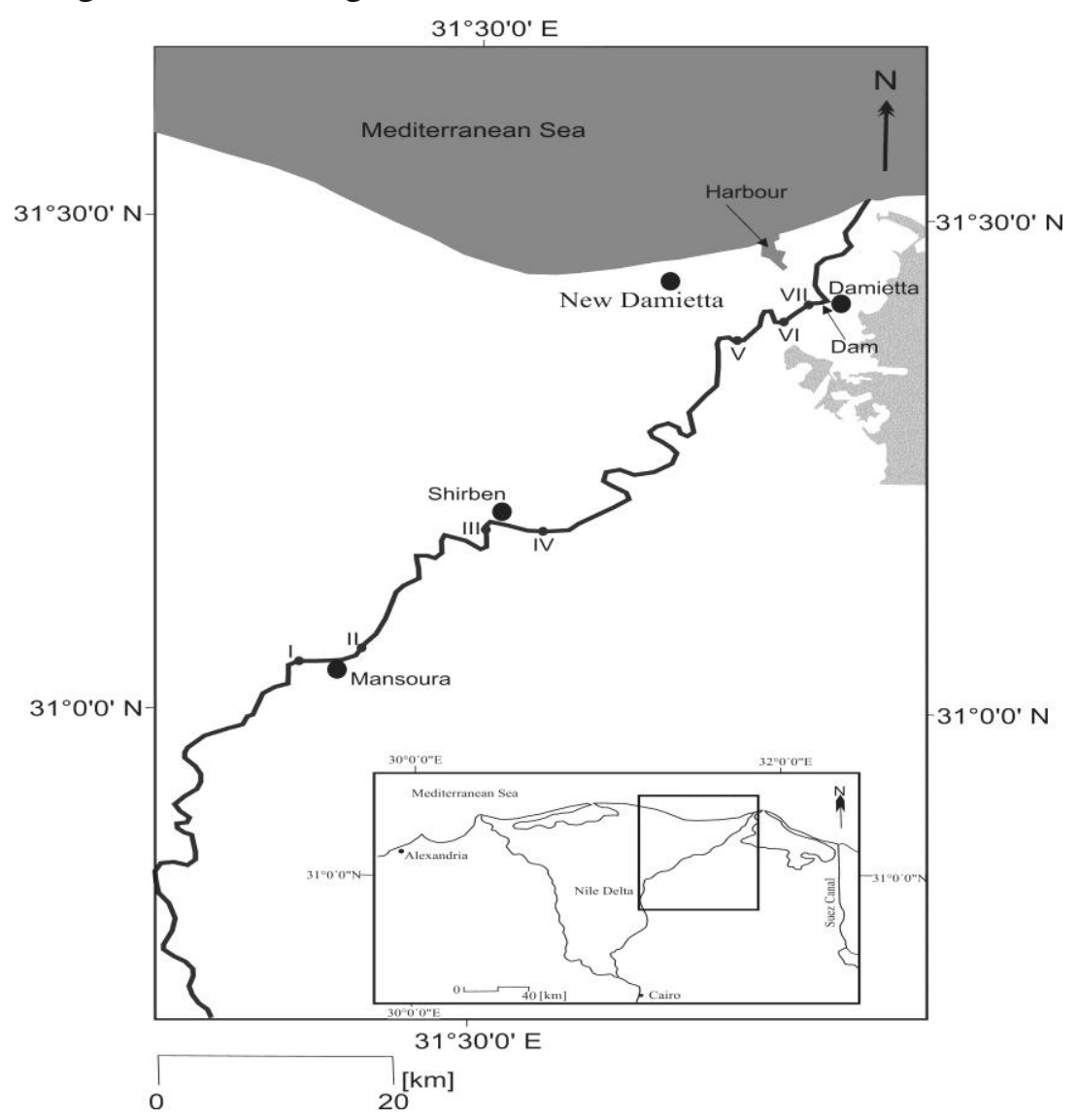

Fig. 1. Map of the study area showing the location of sampling staions.

\section{Sampling and analysis}

Surface water samples were collected concurrently with zooplankton samples for the measurement of physicochemical parameters. Temperature, water transparency, $\mathrm{pH}$, electrical conductivity $(E C)$, total dissolved solids (TDS), and dissolved oxygen $(D O)$ were measured in-situ. In the lab, the analysis of physicochemical parameters namely, chloride $\left(\mathrm{Cl}^{-}\right)$, alkalinity $\left(\mathrm{CaCO}_{3}\right)$, nitrate $\left(\mathrm{NO}_{3}{ }^{-}\right)$, nitrite $\left(\mathrm{NO}_{2}^{-}\right)$, ammonium $\left(\mathrm{NH}_{4}{ }^{+}\right)$, and inorganic dissolved phosphorus $\left(\mathrm{PO}_{4}{ }^{3-}\right)$ was done by standard methods (Clesceri et al., 1999). The phytoplankton biomass (Chlorophyll-a) was determined according to the methods described by Wetzel and Likens (2000).

Mesozooplankton collections were taken using a $180 \mu \mathrm{m}$ mesh plankton ringnet of $65 \mathrm{~cm}$ mouth diameter hauled vertically from the bottom to the surface at each station. Samples were preserved in $4 \%$ buffered formaldehyde. Zooplankton taxa were identified (Balcer et al., 1984; Edmondson, 1959; Koste and Shiel, 1986; Koste and Shiel, 1987) and taxon abundance per cubic meter was determined from a $5 \mathrm{ml}$ subsample, taken with a pipette of the entire sample $(100 \mathrm{ml})$.

\section{Statistical analysis}

Canonical Correspondence Analysis (CCA) was performed to assess the association of mesozooplankton species with physicochemical parameters using the CANOCO 4.5 package (Ter Braak and Smilauer, 2005). A Monte Carlo test was used to evaluate the significance of the environmental factors (El-Tohamy et al., 2018b).SIMPER analysis of similarity percentages between sampling stations was 
applied to identify species contribution in the sampling area [CAP v3.0 (Seaby et al., 2004)]. The TWINSPAN “Two Way Indicator Species Analysis" (Hill et al., 1975) was run using the default options to the second cut level. The significance of variations in environmental factors was assessed by ANOVA with tukey's-b test to determine the significant difference between TWINSPAN groups. One way ANOVA analysis was carried out using the statistical program SPSS v18.0.

\section{RESULTS}

\section{General water quality}

Water temperature varied temporally between a minimum of $19{ }^{\circ} \mathrm{C}$ in January and a maximum of $34.5^{\circ} \mathrm{C}$ in June. The water was slightly alkaline; the $\mathrm{pH}$ range was 7.6-8.72 (Table 1). The water transparency varied significantly between station with values ranged between $39.3 \mathrm{~cm}$ at station IV and $390.8 \mathrm{~cm}$ at station VII. The total dissolved solids (TDS), ranged from $268 \mathrm{mg} \cdot \mathrm{l}^{-1}$ at station VI in July to $686 \mathrm{mgl}^{-}$ ${ }^{1}$ at station II in October with an average of $435 \mathrm{mg}^{-1} \mathrm{l}^{-1}$. Throughout this study, the EC values ranged from 398 at station III in January to $1434 \mu \mathrm{S} \cdot \mathrm{cm}^{-1}$ at station IV in November with an average of $830 \mu \mathrm{S} \cdot \mathrm{cm}^{-1}$. Chlorinity $\left(\mathrm{Cl}^{-}\right)$values varied between 144 to $210 \mathrm{mg} \cdot \mathrm{l}^{-1}$ at the station I in October and August respectively, with an average of $163 \mathrm{mg} \cdot \mathrm{l}^{-1}$. Dissolved oxygen (DO) levels exhibited variable results regarding the site nature. The values ranged from 3.7 to $7.8 \mathrm{mg} \cdot \mathrm{l}^{-1}$ with an average of $5.9 \mathrm{mg} \cdot \mathrm{l}^{-1}$. Nutrient concentrations were considerably high most of the year. Nitrate concentrations showed spatial differences, and in a parallelization with nitrite, the values were highest at station VI and lowest at station I. Ammonium ranged 5 to 550 $\mu \mathrm{g} \cdot \mathrm{l}^{-1}$ (Table 1). Generally, the concentrations were higher at stations I and II compared to other stations. Phosphate concentrations ranged from undetectable limits at stations $\mathrm{V}$ during winter to $>90 \mu \mathrm{g} \mathrm{l}^{-1}$ at the station $\mathrm{I}$ in March. The chlorophyll-a values ranged between 3.2 and $19.6 \mu \mathrm{g} \cdot \mathrm{l}^{-1}$ with an average of 11.13 $\mu \mathrm{g} \cdot \mathrm{l}^{-1}$ (Table 1).

Table 1: Summary of basic descriptive statistics of different physicochemical parameters, and chlorophyll-a.

\begin{tabular}{lcccc}
\hline Component & Mean & Stand.dev. & Minimum & Maximum \\
\hline Temperature $\left({ }^{\circ} \mathrm{C}\right)$ & 28.01 & 4.68 & 19 & 36.33 \\
Transparency $(\mathrm{cm})$ & 179.72 & 155.71 & 30 & 545 \\
pH & 8.21 & 0.35 & 7.6 & 8.72 \\
$\mathrm{DO}\left(\mathrm{mgl}^{-1}\right)$ & 5.91 & 0.78 & 3.68 & 7.83 \\
$\mathrm{Alkalinity}\left(\mathrm{mgl}^{-1}\right)$ & 825.3 & 182.9 & 672.7 & 1438 \\
$\mathrm{EC}\left(\mu \mathrm{scm}^{-1}\right)$ & 829.83 & 342 & 397.67 & 1433.67 \\
$\mathrm{TDS}\left(\mathrm{mgl}^{-1}\right)$ & 435.26 & 117.17 & 276.67 & 686.33 \\
$\mathrm{Cl}^{-}\left(\mathrm{mgl}^{-1}\right)$ & 163.26 & 15.28 & 143.92 & 209.64 \\
$\mathrm{NO}_{2}^{-}\left(\mu \mathrm{gl}^{-1}\right)$ & 40 & 20 & 17 & 95 \\
$\mathrm{NO}_{3}{ }^{-}\left(\mu \mathrm{gl}^{-1}\right)$ & 100 & 47 & 35 & 200 \\
$\mathrm{NH}_{4}{ }^{+}\left(\mu \mathrm{gl}^{-1}\right)$ & 270 & 130 & 3 & 550 \\
$\mathrm{PO}_{4}{ }^{3-}\left(\mu \mathrm{gl}^{-1}\right)$ & 19 & 25 & 0 & 93 \\
${\mathrm{Chlorophyll-a}\left(\mu \mathrm{gl}^{-1}\right)}^{11.13}$ & 4.32 & 3.25 & 19.57 \\
\hline
\end{tabular}

\section{Zooplankton community and abundance}

A total of 36 mesozooplankton species were identified during the present study along the Nile River Damietta Branch, including 12 rotifers, 1 nematode, 8 cladocerans, 10 copepods, and 5 ostracodes. The highest diversified communities (12 taxa) were reported at station $\mathrm{V}$ in winter, while the lowest $(7$ taxa) occurred at 
station VI during autumn and winter (Fig. 2). The present results reported pronouncedly high variations of mesozooplankton standing crop, whereas the total count over the study area varied from $<300$ individual $\mathrm{m}^{-3}$ at stations $\mathrm{V}$ and VI during winter and summer respectively to $>2300$ individuals $\mathrm{m}^{-3}$ in winter at the station VII (Fig. 2), with an annual average of 931.7 individuals $\mathrm{m}^{-3}$.
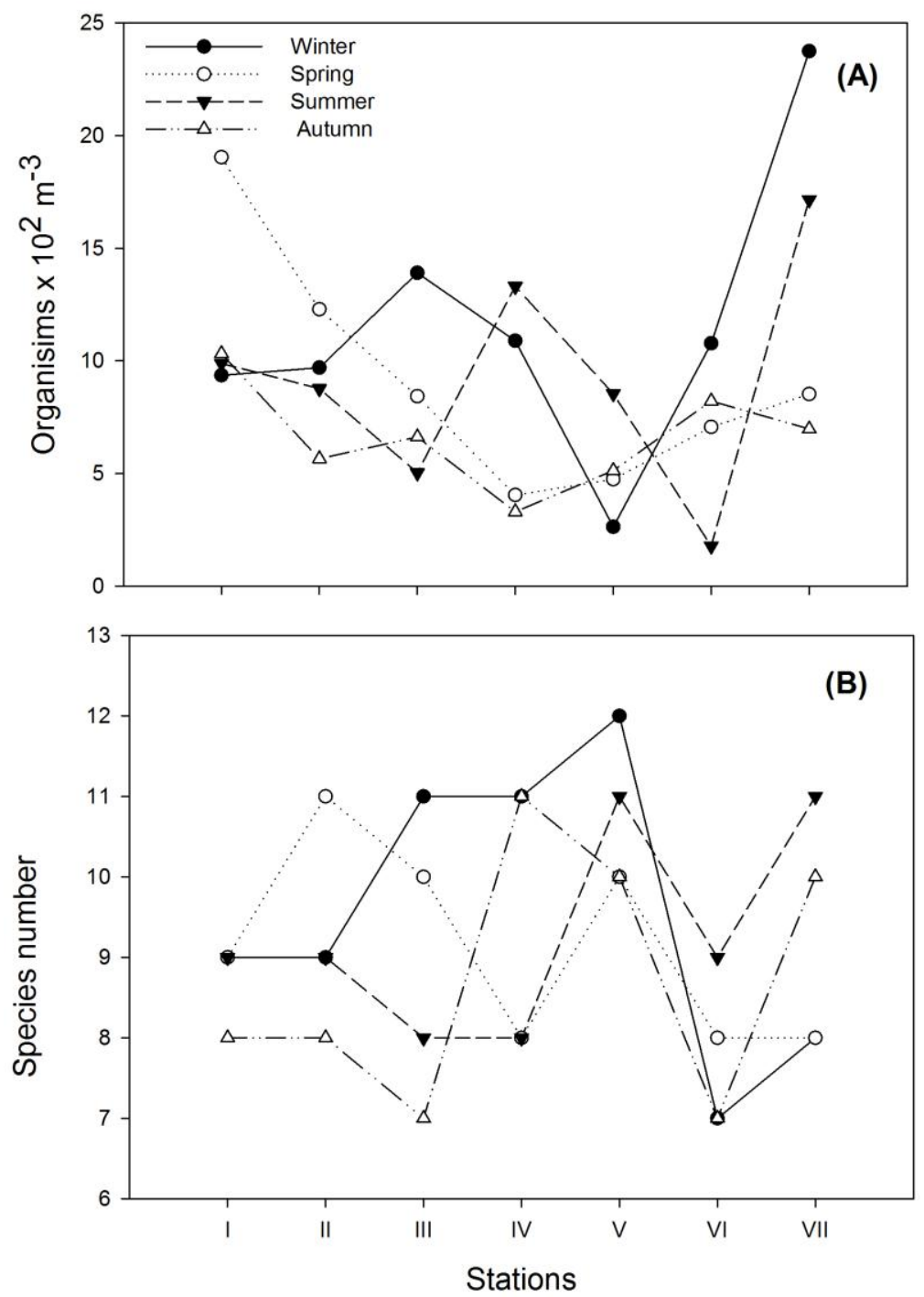

Fig. 2: Seasonal variations of mesozooplankton abundance (A) and species number (B) at the sampled stations.

Crustaceans were the most abundant component, representing $84.62 \%$ and 63.9 $\%$ of the total abundance and species richness respectively. Cladocerans dominated the Crustacea community structure, representing $>49 \%$ of their total abundance. On the temporal scale, the cladocerans had the maximum role in winter at stations II and IV, in spring at stations II, V, and VI (Fig. 3). According to SIMPER analysis; Bosmina longirostris, Ceriodaphnia reticulate, Moina micura, and Chydours sphaericus were the dominant cladocerans and demonstrating the highest active contributors to the total mesozooplankton count between the sampling stations (Table 2). The former three dominant species contributed collectively about 8-19\% and $8-22 \%$ of total crustaceans and total mesozooplankton respectively. Copepods 
represented the second predominant group, accounting for $35.3 \%$ and $29.9 \%$ of the total crustaceans and the total mesozooplankton respectively over the whole study area.

Table 2: Species list in the study area which is ranked according to SIMPER analysis. Abbrev.= Species abbreviation, Cont. $\%=$ the percentage of species contribution to the total mesozooplankton abundance.

\begin{tabular}{|c|c|c|c|}
\hline Name & Classification & Abbrev. & Cont. \% \\
\hline Bosmina longirostris (O.F. Müller, 1785) & Cladocera & Boslo & 8.4 \\
\hline Ceriodaphnia reticulata (Jurine, 1820) & Cladocera & Cerre & 5.4 \\
\hline Moina micrura (Kurz, 1875) & Cladocera & Momi & 6 \\
\hline Acanthocyclops americanus (Marsh, 1893) & Copepoda-Cyclopoida & Acam & 3.9 \\
\hline Brachionus calyciflorus (Pallas, 1766) & Rotifera & Brca & 4 \\
\hline Copepodites & Copepoda & Copd & 3.7 \\
\hline Candona subgibba (G. O. Sars, 1926) & Ostracoda & Casu & 5.4 \\
\hline Chydorus sphaericus (O.F. Müller, 1776) & Cladocera & Chsp & 3.1 \\
\hline Brachionus quadridentatus (Hermann, 1783) & Rotifera & Brqu & 3.2 \\
\hline Ephippium of Cladocera & Cladocera & Ephcl & 2.9 \\
\hline Trichocerca sp. & Rotifera & Trsp & 2.5 \\
\hline Nauplii larvae & Copepoda & Naup & 2.7 \\
\hline Synchaeta sp. & Rotifera & Sysp & 1.2 \\
\hline Alona rectangula (G.O. Sars, 1862) & Cladocera & Alre & 2.9 \\
\hline Mesocyclops leuckarti (Claus, 1857) & Copepoda-Cyclopoida & Mele & 2.9 \\
\hline Brachionus plicatilis (Müller, 1786) & Rotifera & Brpli & 2.6 \\
\hline Halicyclops magniceps (Lilljeborg, 1853) & Copepoda-Cyclopoida & Hama & 3.1 \\
\hline Eothinia elongata (Ehrenberg, 1832) & Rotifera & Eoel & 2.5 \\
\hline Asplanchna priodonta (Gosse, 1850) & Rotifera & Aspr & 2.3 \\
\hline Eucyclops speratus (Lilljeborg, 1901) & Copepoda Cyclopoida & Eusp & 2.7 \\
\hline Diaphanosoma excisum (G.O. Sars, 1885) & Cladocera & Diexc & 1.9 \\
\hline Proales similis (de Beauchamp, 1907) & Rotifera & Prsi & 1.9 \\
\hline Potamocypris variegata (Brady \& Norman, 1889) & Ostracoda & Pova & 4.4 \\
\hline Oithna sp. & Copepoda-Cyclopoida & Oisp & 1.9 \\
\hline Onychocamptus mohammed (Blanchard \& Richard, & Copepoda Harpacticoida & Onmo & 3 \\
\hline $\begin{array}{l}\text { Mo1) } \\
\text { Monostyla bulla (Gosse 1886) }\end{array}$ & Rotifera & Mobu & 0.3 \\
\hline Cypria pellucida (G. O.Sars, 1901) & Ostracoda & Cypel & 2.1 \\
\hline Colurella sp. & Rotifera & Cosp & 1.5 \\
\hline Lecane depressa (Bryce, 1891) & Rotifera & Lede & 1.5 \\
\hline Insect larvae & Hexapoda & Inla & 1.8 \\
\hline Macrothrix hirsuticornis (Norman \& Brady 1867) & Cladocera & Mahir & 1.7 \\
\hline Limnocythere inopinata (Baird, 1843) & Ostracoda & Liino & 1.5 \\
\hline Platyias quadricornis (Ehrenberg, 1832) & Rotifera & Plqu & 0.3 \\
\hline Cypria obesa (Sharpe, 1897) & Ostracoda & Cyobe & 1.1 \\
\hline Diacyclops bicuspidatus odessanus (Schmankevitsch, & Copepoda-Cyclopoida & Dibi & 1 \\
\hline $\begin{array}{l}\text { 1875) } \\
\text { Oxyurella longicaudis (Birge, 1910) }\end{array}$ & Cladocera & Oxlo & 0.8 \\
\hline Nitokra lacustris (Shmankevich, 1875) & Copepoda- Harpacticoida & Nila & 0.7 \\
\hline Diaptomus minutus (Lilljeborg \& Richard, 1889) & Copepoda-Calanoida & Dimi & 0.4 \\
\hline Dorylaimus sp. & Nematoda & Dosp & 0.7 \\
\hline
\end{tabular}


Copepods reported their greatest role in autumn at stations V, VI, and VII, in summer at station III. According to SIMPER analysis; Acanthocyclops americanus, Mesocyclops leuckartii, and Halicyclops magniceps were the most important species, contributing on average $8,3.4$ and $2 \%$ to the total crustacea community respectively, and $1.7-6.7 \%$ to the total mesozooplankton. Ostracodes accounted for $13.2 \%$ of the total mesozooplankton and $15.55 \%$ of total crustaceans. They reported their maximum role in spring at station IV, in winter at station VII (Fig. 3). Candona subgibba and Potamocypris variegata were numerically abundant among the ostracodes, and on average they contributed 8.2 and $3.2 \%$ of the total mesozooplankton abundance respectively. Although, the high diversity of rotifers (13 taxa), they contributed only $14.8 \%$ of the total abundance. According to SIMPER analysis (Table 2), Brachionus calyciflorus, B. quadridentatus, and Trichocerca sp. were the most abundant species, contributing on average $29.6,17$, and $6.4 \%$ of the total rotifers abundance respectively, and $4,2.5$ and $1.9 \%$ of the total mesozooplankton abundance respectively. Other taxa encompassed only the nematode Dorylaimus sp. in addition to the meroplanktonic insect larvae (Table 3), contributed collectively $<1 \%$ of the total abundance.

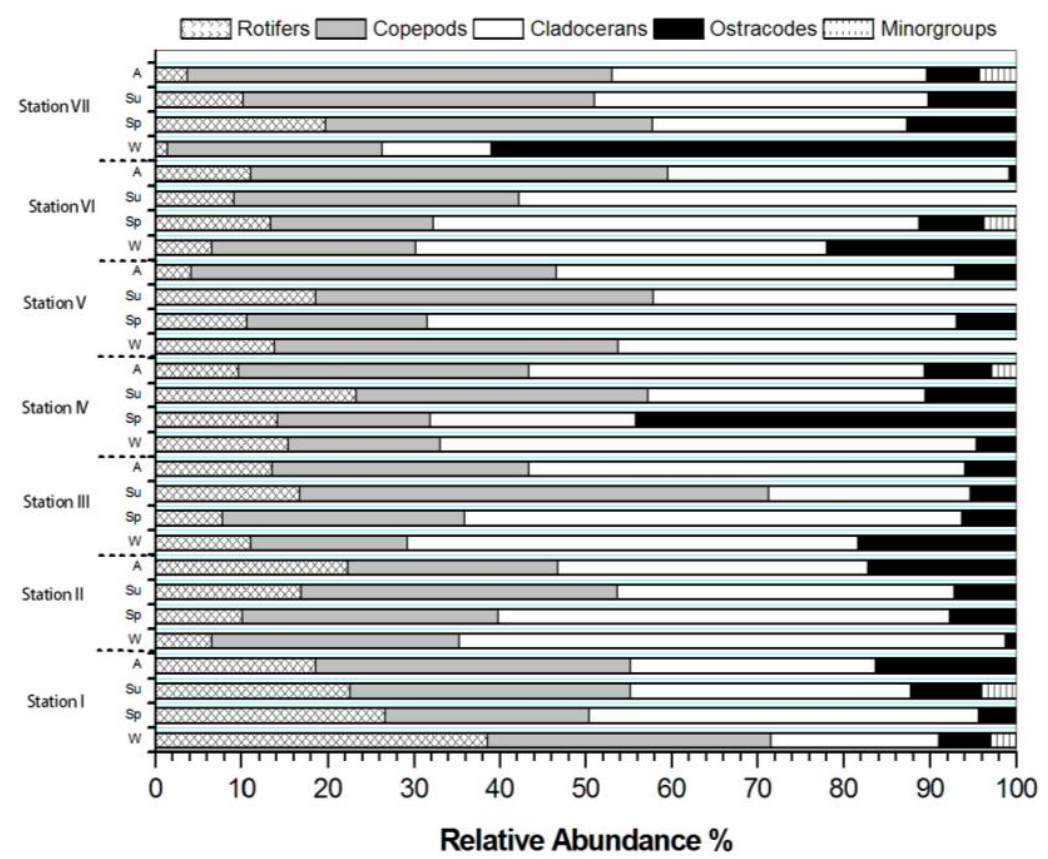

Fig. 3: Seasonal relative abundance of the major zooplankton groups at the sampled stations.

Table 3: The relative richness and abundance of the main mesozooplankton groups.

\begin{tabular}{llcccc}
\hline Category & & \multicolumn{3}{c}{ Species } & \multicolumn{3}{c}{ Mean Abundance } \\
\hline \multirow{2}{*}{ Rotifera } & & Number & $\%$ & Ind.m $^{-3}$ & $\%$ \\
Nematoda & & 12 & 33.3 & 137.9 & 14.8 \\
& Cladocera & 1 & 2.8 & 1.5 & 0.2 \\
Crustacea & Ostracoda & 8 & 22.2 & 387.4 & 41.6 \\
Crustacea & Copepod & 5 & 13.9 & 122.6 & 13.2 \\
Insect Larvae & & 10 & 27.8 & 278.4 & 29.9 \\
Total & & - & - & 3.6 & 0.4 \\
\hline
\end{tabular}




\section{ROT: CLA: COP ratio}

The ROT:CLA:COP ratio in the study area, which constituted 0.16:0.52:0.32 in the Winter, achieved 0.19:0.49:0.31 in the Spring during the eutrophication development and changed to be 0.17:0.45:0.39 and 0.17:0.46:0.37 in summer and autumn respectively. These ratios are suggesting an increase in the eutrophication with increasing temperature values from spring to autumn. Also, the ratios indicated a relative decrease in the density of rotifers when compared with that of copepods or cladocerans.

\section{The TWINSPAN analysis}

A data set of 84 samples that contains zooplankton species in the study area was analyzed using two-way indicator species analysis (TWINSPAN). The results classify mesozooplankton samples to four groups or clusters labeled A-D (Fig. 4). Each group includes a set of samples with higher similarity of species as compared to other groups. Each cluster is characterized by indicator species identified by TWINSPAN at each level of hierarchical classification. In the following description, the groups are characterized in terms of their indicator species.

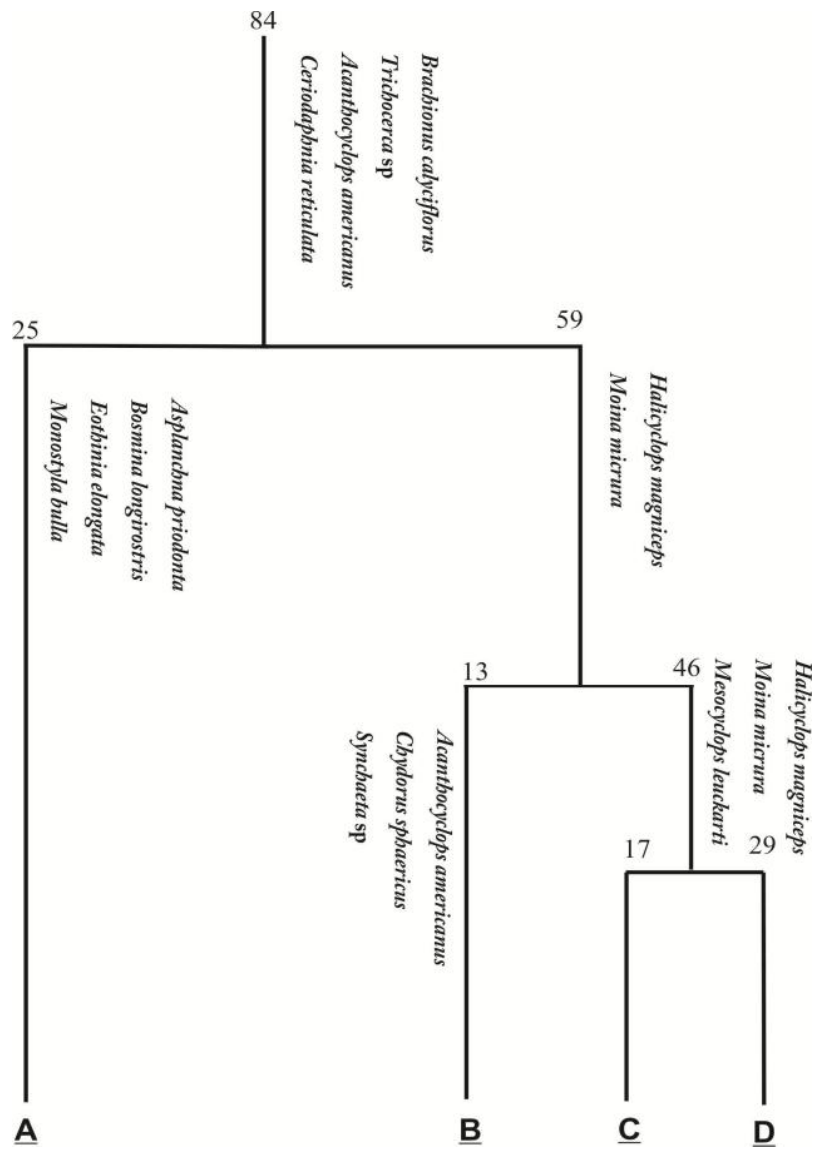

Fig. 4: TWINSPAN dendrogram of 84 samples based on the density of zooplankton species in the study area. Indicator species are shown at each level of classification. Four groups (A-D) are shown at level 2.

Group A: including 25 samples from stations II and VI; the group is characterised by Asplanchna priodonta, Bosmina longirostris, Eothinia elongate, and Monostyla bulla as indicator species.

Group B: comprises 13 samples mostly from the station I and indicated by Acanthocyclops americanus, Chydorus sphaericus, and Synchaeta sp.. 
Groups C and D: 46 samples including the sample units from stations III, IV, V, and VII with Halicyclops magniceps, Moina micrura, and Mesocyclops leuckartii as indicator species.

As shown in Table 4, group $\mathrm{A}$ is associated with the highest values of temperature, alkalinity, phytoplankton biomass, and the lowest phosphate values, while group $\mathrm{B}$ was associated with the highest values of $\mathrm{pH}$, dissolved oxygen, and the lowest values of temperature and phytoplankton biomass. On the other hand, groups $\mathrm{C}$ and $\mathrm{D}$ appeared to be in accordance with relatively higher values of nutrients and chlorophyll-a.

Table 4: Means of 13 environmental parameters recorded in different TWINSPAN groups. Mean of the variables have the Latin letters of the groups which are significantly different according to the Tuckey's-b test.

\begin{tabular}{|c|c|c|c|c|c|c|}
\hline & \multicolumn{4}{|c|}{ TWINSPAN groups } & \multicolumn{2}{|c|}{$A N O V A$} \\
\hline & $\mathbf{A}$ & $B$ & $C$ & D & $\mathbf{F}$ & $\mathbf{p}$ \\
\hline Temperature & $34.3^{1}$ & $21^{\mathrm{III}}$ & $26.5^{I I}$ & $28.2^{I I}$ & 29.8 & $<0.001$ \\
\hline Transparency & 269.6 & 195 & 166.3 & 132.1 & 1.7 & 0.177 \\
\hline $\mathrm{pH}$ & $8.1^{\mathrm{II}}$ & $8.6^{\mathbf{I}}$ & $8.2^{\text {II }}$ & $8.0^{\mathrm{II}}$ & 5.5 & 0.002 \\
\hline DO & $7.5^{\mathrm{II}}$ & $9^{I}$ & $8.2^{\mathrm{I}}$ & $7.5^{\mathrm{II}}$ & 6.21 & 0.001 \\
\hline Alkalinity $(A L K)$ & $976.7^{\mathrm{I}}$ & $747.9^{\text {II }}$ & $817.9^{\text {I }}$ & $757.7^{\text {II }}$ & 4.42 & 0.006 \\
\hline$E C$ & 902.4 & 648.2 & 759.6 & 866.8 & 1.2 & 0.344 \\
\hline$T D S$ & 461.5 & 403.7 & 383.2 & 454.5 & 1.7 & 0.18 \\
\hline $\mathrm{Cl}^{-}$ & 162.2 & 176.5 & 162.3 & 160.6 & 1.14 & 0.34 \\
\hline $\mathrm{NO}_{2}^{-}$ & 37.7 & 51.7 & 35.6 & 40.5 & 0.6 & 0.6 \\
\hline $\mathrm{NO}_{3}^{-}$ & $71.2^{\text {II }}$ & $79.3^{\text {II }}$ & $129.9^{I}$ & $132.4^{\text {I }}$ & 2.84 & 0.04 \\
\hline $\mathrm{NH}_{4}^{+}$ & 156.7 & 226.8 & 259.0 & 256.4 & 1.8 & 0.1 \\
\hline $\mathrm{PO}_{4}{ }^{3-}$ & $3.9^{\text {III }}$ & $44.7^{\text {I }}$ & $18.4^{\mathrm{II}}$ & $24.3^{\text {II }}$ & 2.61 & 0.05 \\
\hline Chlorophyll-a & $14.5^{\mathrm{I}}$ & $5.2^{\mathrm{II}}$ & $10.8^{I}$ & $12.0^{I}$ & 10.26 & $<0.001$ \\
\hline
\end{tabular}

\section{The multivariate analysis}

The DCA results showed that the maximum length of gradients was 2.66, suggesting a linear or unimodal relationship between zooplankton species and environmental parameters. Therefore, both Redundancy analysis (RDA) and Canonical Correspondence analysis (CCA) were performed. The CCA was chosen because it explains more variance in the species distribution than the RDA in the first four axes (RDA: $12.5 \%$, CCA: 15.1\%). The results of CCA indicated that the environmental parameters had a significant influence on mesozooplankton distribution $(\mathrm{F}-$ ratio $=3.02$, P-value $=0.005)$, explaining $56.7 \%$ of the total variance. By using the Monte Carlo permutations test, six environmental parameters had significant influences on the species distribution, among them temperature, conductivity, nitrate, and $\mathrm{pH}$ were the most powerful (Table 5). The ordination diagram produced by CCA shows the distribution pattern of mesozooplankton species along the environmental gradients. As shown in figure 5, more than $65 \%$ of rotifers and cladocerans were found in the right half of the ordination diagram where the gradients of temperature and phytoplankton biomass in opposition with the vectors of dissolved oxygen, $\mathrm{pH}$, and nutrients, especially at stations II and VI. On the other hand, at the other stations, ostracodes and 90\% of copepods were associated mainly with the gradients of $\mathrm{pH}$, dissolved oxygen, TDS, and nutrients opposite to the vectors of temperature and phytoplankton biomass. The cladocerans Bosmina longirostris and Ceriodaphnia reticulate, and the rotifers Asplanchna priodonta and Brachionus plicatilis were associated with gradients of temperature and phytoplankton biomass, especially at stations II and VI. The vectors of chloride and conductivity found mostly between the sample units from station VII. The rotifer 
Brachionus calyciflorus, the ostracod Cypria pellucida, the harpacticoide Onychocamptus mohammed, and the cladoceran Diaphanosoma excisum were associated with these vectors (Figure 5). The cladocerans Alona rectangula and Chydorus sphaericus, the copepods Acanthocyclops americanus, Nitokra lacustris, and the rotifer Synchaeta sp. were associated with the highest values of $\mathrm{pH}$ and dissolved oxygen at station I. The genera which close to the point of diagram origin (0-0) as Candona subgibba, Trichocerca Sp, the copepod nauplii and copepodites indicated the homogonus distribution of these species at all sampled stations. The other species as Lecane depressa, Halicyclops magniceps, Mesocyclops leuckartii, Diaptomus minutus, Moina micrura, and Limnocythere inopinata were associated with the vectors phosphate and opposite to the vectors of temperature transparency at stations IV and V (Figure 5).

Table 5: Results of forwarding selection and Monte Carlo permutation tests from CCA.

\begin{tabular}{lccc}
\hline Variables & Lambda- $\boldsymbol{A}$ & $\boldsymbol{F}$-ratio & $\boldsymbol{P}$-value \\
\hline Temperature & 0.15 & 3.02 & 0.005 \\
$E C$ & 0.1 & 2.06 & 0.005 \\
$\mathrm{NO}_{3}{ }^{-}$ & 0.08 & 1.79 & 0.015 \\
$\mathrm{pH}$ & 0.08 & 1.75 & 0.04 \\
$\mathrm{Cl}^{-}$ & 0.08 & 1.74 & 0.02 \\
$\mathrm{PO}_{4}{ }^{3-}$ & 0.07 & 1.38 & 0.04 \\
$\mathrm{Alkalinity}_{\mathrm{NH}_{4}{ }^{-}}$ & 0.06 & 1.32 & 0.159 \\
$\mathrm{Transparency}_{\mathrm{NO}}^{-}$ & 0.05 & 1.14 & 0.328 \\
$\mathrm{DO}$ & 0.05 & 1.09 & 0.323 \\
$\mathrm{TDS}$ & 0.05 & 1.03 & 0.388 \\
$\mathrm{Chlorophyll-a}$ & 0.04 & 0.99 & 0.493 \\
\hline
\end{tabular}
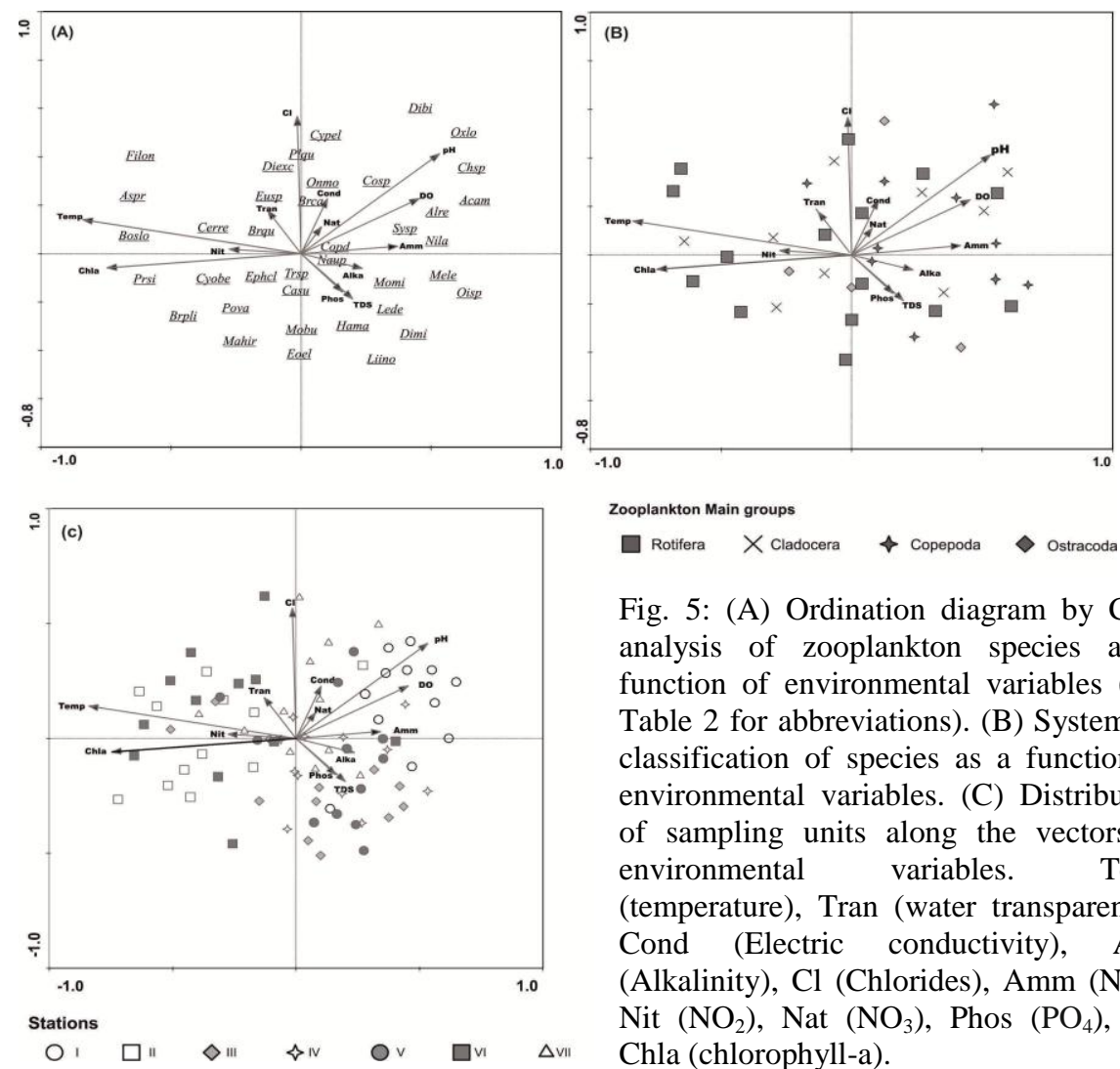

Zooplankton Main groups

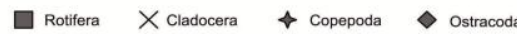

Fig. 5: (A) Ordination diagram by CCA analysis of zooplankton species as a function of environmental variables (See Table 2 for abbreviations). (B) Systematic classification of species as a function of environmental variables. (C) Distribution of sampling units along the vectors of environmental variables. Temp (temperature), Tran (water transparency), Cond (Electric conductivity), Alka (Alkalinity), $\mathrm{Cl}$ (Chlorides), Amm $\left(\mathrm{NH}_{4}\right)$, Nit $\left(\mathrm{NO}_{2}\right)$, Nat $\left(\mathrm{NO}_{3}\right)$, Phos $\left(\mathrm{PO}_{4}\right)$, and Chla (chlorophyll-a). 


\section{DISCUSSION}

The available data existing in the literature on the Nile River Damietta Branch zooplankton community structure were provided by Helal $(1981 ; 2006)$. However, the present study is limited by the large mesh size used $(180 \mu \mathrm{m})$. The recorded pattern of zooplankton in this study reflects the use of coarse mesh size. This coarse mesh net causes the undersampling of small zooplankton specimens such as rotifers and small copepods, which probably lead to an underestimation of the total zooplankton abundances (Chisholm and Roff, 1990). Accordingly, zooplankton abundances in the present study were significantly lower than those found in other areas along the Egyptian part of Nile River, such as upper Egypt (El-Bassat, 1995; El-Otify and Iskaros, 2015; Rzoska, 1976), Rosetta Branch (Abdel-Halim et al., 2013; El-Shabrawy and Khalifa, 2002; Hegab, 2010), and that studied previously in Damietta Branch by Helal $(1981 ; 2006)$. On the other hand, most of the standard sampling protocols for zooplankton in the Egyptian waters are restricted only to mesh sizes $<60 \mu \mathrm{m}$. This reduction in mesh size may be inappropriate for mesozooplankton collection with the loss of many species through the filtration process (Tseng et al., 2011). According to Sosnovsky and others (2016), the mesozooplankton community comprises mostly copepods and cladocerans. In the 1981 study (Helal, 1981), cladocerans were represented by six different species decreased to four species in 2006 study (Helal, 2006), whereas in the present study the group was represented by eight species. The copepods were represented by ten species in the current investigation, against eight species in 1981 study. Also, AbdelHalim and others (2013) recorded only six different species of copepods in the Rosetta Branch. The significant increase in the number of mesozooplankton species, especially among copepods and cladocerans, is indicative of the advantages of coarse mesh in the collection of mesozooplankton.

The CCA ordination analysis revealed that the considerable variations in different mesozooplankton groups among sampling stations were significantly correlated with the variations of temperature, conductivity, and nitrate concentrations. This confirms with the observations in other areas, where the water temperature was a keystone element in the seasonal dynamics of mesozooplankton (Jerling and Weerts, 2018; Nakajima et al., 2017), and may regulate most ecological mechanisms in temperate areas (Sellami et al., 2010). As mentioned by El-Tohamy (2018a), the study area receives relatively high anthropogenic disturbance, directly or indirectly resulting in high values of nutrients and conductivity. According to Dorak (2014), the conductivity variation may regulate the structure of zooplankton assemblages, especially the spatial changes in species diversity and abundance.

The particular thermal and trophic conditions are shaping the occurrence and the spatial distribution of zooplankton in the study area. This is related to the quantity and quality of the post-cooling waters that discharged into the river system which resulted in the decrease in abundance and diversity of mesozooplankton particularly at stations II and VI in comparison to other stations. The impact of the discharge of thermal power generation plant post-cooling waters on zooplankton diversity, spatial distribution, and abundance have been stated in many studies (Gromova and Protasov, 2017; Hillbricht-Ilkowska and Zdanowski, 1989; Kulakov et al., 2018; Tunowski, 2009; Zdanowski, 1988). According to Zdanowski and Prusik (1994), the changes in thermal regimes and chemical composition of waters have significant impacts on the metabolism of planktonic organisms. 
Although the CCA ordination was explaining 56.7\% of the total variations of the mesozooplankton community of Damietta Branch-Nile River, a significant amount of the total variations remains unexplained. Some portion of the unexplained variation in the recorded zooplankton data may be associated with the primary productivity (opposing the merely using of chlorophyll-a as a proxy for phytoplankton standing crop). According to Emerson and other (2015), the variations in chlorophyll-a concentrations were not strong explanatory of the zooplankton community, indicating the need for an effective way for the primary production determination. Other unexplained factors that may need future study include zooplankton predation by fishes and invertebrates and competition between zooplankton taxa.

TWINSPAN analysis demonstrated the tight relationship between the spatial distribution of zooplankton and the environmental characteristics in the study area. The analysis grouped the sampling points that are sufficiently similar into two main clusters. The first cluster (warm-water community of stations II and VI) seemed to be clearly separated from the other cluster groups (Fig. 4). The indicator species of each TWINSPAN group differed in relation to the prevalence of different environmental conditions. For example, the cladocerans Bosmina longirostris is a polythermal species (Di Genaro et al., 2015) and their population growth usually increases at a temperature above $22{ }^{\circ} \mathrm{C}$, which supports their rapid rise to dominance particularly at stations II and VI. Also, the distribution pattern of other indicator species found in the present study was clearly influenced by the combination of the influences of postcooling waters and other environmental factors. In the first cluster, there were some warm-water species, such as the rotifers Asplanchna sp. and Monostyla sp., whereas there were some cold-water rotifer species indicated the second cluster such as Keratella quadrata and Synchaeta sp.. This is in agreement with Yin et al. (2018), who reported that the rotifers Asplanchna sp. and Monostyla sp. preferred the warmwater habitat, whereas Keratella quadrata and Synchaeta sp. preferred cold-water. The CCA biplot also showed that the abundance of Bosmina longirostris, Asplanchna sp. and Monostyla sp., were significantly correlated with temperature.

The ROT:CLA:COP ratio was applied to detect how the eutrophication process changes the contribution of rotifers, cladocerans, and copepods communities to the total zooplankton abundance (Adamczuk et al., 2015). In the present study, we observed that Cladocera and Copepoda were contributed largely than Rotatoria in the process of eutrophication all year round. Also, the ratio of calanoid copepods to cladocerans and cyclopoids frequently used as a good indicator of trophic conditions in freshwater ecosystems (Gannon and Stemberger, 1978; Jeppesen et al., 2011; Montagud et al., 2019). Calanoids are more adapted to oligotrophic conditions while cyclopoids and cladocerans are usually more abundant with increasing eutrophication (Adamczuk et al., 2015). That statement was confirmed by similar observations in the study area, the significantly decreased ratio of calanoid copepods (represented only by Diaptomus minutus) to cladocerans and cycloids copepods indicated the eutrophication process.

\section{CONCLUSION}

This study represented a comprehensive investigation of the mesozooplankton community of this poorly studied area in the Nile River. The main factor influencing the abundance and distribution of the mesozooplankton assemblages was the water temperature. The low species richness and density 
obtained at stations II and VI that are directly exposed to the discharge of heated waters. Lastly, but not less important, the present work identified that the studying of the mesozooplankton role in aquatic habitat could be better with relatively coarser nets, enabling us to avoid many factors that could affect sampling efficiency such as avoidance, escape and clogging.

\section{CONFLICT OF INTEREST}

The authors declare that they have no conflict of interest.

\section{REFERENCES}

Abdel-Halim, A.; Waheed, M.; Gamal, M. and Fawzia, M. (2013). Sewage pollution and zooplankton assemblages along the Rosetta Nile Branch at El Rahawy area, Egypt. Int. J. Environ. Sci. Eng., 4: 29 - 45.

Adamczuk, M.; Mieczan, T.; Tarkowska-Kukuryk, M. and Demetraki-Paleolog, A. (2015). Rotatoria-Cladocera-Copepoda relations in the long-term monitoring of water quality in lakes with trophic variation (E. Poland). Environ. Earth Sci., 73(12): $8189-8196$.

Arthington, Á. H.; Naiman, R. J.; Mcclain, M. E. and Nilsson, C. (2010). Preserving the biodiversity and ecological services of rivers: new challenges and research opportunities. Freshwater Biol., 55(1): 1-16.

Balcer, M. D.; Korda, N. L. and Dodson, S. I. (1984). Zooplankton of the Great Lakes: a guide to the identification and ecology of the common crustacean species. Univ of Wisconsin Press.

Bum, B. K. and Pick, F. R. (1996). Factors regulating phytoplankton and zooplankton biomass in temperate rivers. Limnol. Oceanogr., 41(7): 1572 1577.

Buskey, E.; Lenz, P. and Hartline, D. (2002). Escape behavior of planktonic copepods in response to hydrodynamic disturbances: high speed video analysis. Mar. Ecol. Prog. Ser., 235: 135-146.

Chisholm, L. and Roff, J. (1990). Abundances, growth rates, and production of tropical neritic copepods off Kingston, Jamaica. Mar. Biol., 106(1): $79-89$.

Clesceri, L. S.; Greenberg, A. E. and Eaton, A. D. (1999). Standard Methods for Examination of Water and Wastewater:20th Edition. Amer Public Health Assn; 20th edition (January 1999): Washington, DC.

Di Genaro, A. C.; Sendacz, S.; Moraes, M. d. A. B. and Mercante, C. T. J. (2015). Dynamics of Cladocera community in a tropical hypereutrophic environment (Garças Reservoir, Sao Paulo, Brazil). J. Water Resource Prot., 7(5): 379 388.

Dorak, Z. (2014). Zooplankton abundance in the lower Sakarya River Basin (Turkey): Impact of environmental variables. J. Black Sea/Mediterranean Environ., 19(1): $1-22$.

Edmondson, W. T. (1959). Freshwater biology. 2nd ed. John Wiley and sons: New York London Sydney.

El-Bassat, R. (1995). Ecological studies on zooplankton in the River Nile. M.Sc. Thesis, Oceanography Department, Faculty of ScienceSuez Canal University, Ismalia. 
El-Otify, A. M. and Iskaros, I. A. (2015). Water quality and potamoplankton evaluation of the Nile River in Upper Egypt. Acta Limnol. Bras., 27(2): 171 190.

El-Shabrawy, G. and Khalifa, N. (2002). Zooplankton abundance and community structure in the northern part and estuary of Rosetta Nile Branch in relation to some environmental variables. Egypt. J. Aquat. Biol. Fish., 6(4): $69-90$.

El-Tohamy, W. S.; Abdel-Baki, S. N.; Abdel-Aziz, N. E. and Khidr, A. A. A. (2018a). Evaluation of Spatial and Temporal Variations of Surface Water Quality in the Nile River Damietta Branch. Ecol. Chem. Eng., S, 25(4): 569 580.

El-Tohamy, W. S.; Hopcroft, R. R. and Abdel Aziz, N. E. (2018b). Environmental Determinants of Zooplankton Community in the Damietta Estuary of the Nile River, Egypt. Pak. J. Zool., 50(5): $1785-1798$.

Emerson, J. E.; Bollens, S. M. and Counihan, T. D. (2015). Seasonal dynamics of zooplankton in Columbia-Snake River reservoirs, with special emphasis on the invasive copepod Pseudodiaptomus forbesi. Aquat. Invasions., 10(1): 25 - 40.

Gannon, J. E. and Stemberger, R. S. (1978). Zooplankton (especially crustaceans and rotifers) as indicators of water quality. Trans. Am. Microsc. Soc., 97(1): 16-35.

Gromova, Y. F. and Protasov, A. (2017). Spatial Heterogeneity of Zooplankton in the Water Bodies of the Khmelnytsk NPP Technoecosystem. Hydrobiol. J., 53(5): $12-25$.

Hegab, M. (2010). Ecological studies on zooplankton and the relationships between them and food and feeding of some fish in Rosetta Branch (River Nile), Egypt. M.Sc. Thesis, Zoology Department, Faculty of Science, Al-Azhar University, Cairo.

Helal, H. A. (1981). Studies on the zooplankton of Darnietta Branch of the River Nile north of El-Mansoura. M.Sc. Thesis, Zoology Department, Faculty of Science. Mansoura University, Mansoura.

Helal, H. A. (2006). Decline in zooplankton diversity in the Damietta Branch of the Nile River, Egypt: a comparative study with a 24-year span. Internationale Vereinigung für theoretische und angewandte Limnologie: Verhandlungen, 29(4): $2068-2070$.

Hill, M.; Bunce, R. and Shaw, M. (1975). Indicator species analysis, a divisive polythetic method of classification, and its application to a survey of native pinewoods in Scotland. J. Ecol., 63(2): $597-613$.

Hillbricht-Ilkowska, A. and Zdanowski, B. (1989). Main changes in the Konin lake system (Poland) under the effect of heated-water discharge pollution and fishery. Pol. J. Ecol., 36: $23-45$.

Hopcroft, R.; Roff, J. and Lombard, D. (1998). Production of tropical copepods in Kingston Harbour, Jamaica: the importance of small species. Mar. Biol., 130(4): $593-604$.

Jeppesen, E.; Nõges, P.; Davidson, T. A.; Haberman, J.; Nõges, T.; Blank, K.; Lauridsen, T. L.; Søndergaard, M.; Sayer, C. and Laugaste, R. (2011). Zooplankton as indicators in lakes: a scientific-based plea for including zooplankton in the ecological quality assessment of lakes according to the European Water Framework Directive (WFD). Hydrobiologia, 676(1): 279 297.

Jerling, H. and Weerts, S. P. (2018). Mesozooplankton of the Kosi Bay lakes, South Africa. Afr. J. Aquat. Sci., 43(1): $71-77$. 
Joseph, B. and Yamakanamardi, S. M. (2011). Monthly changes in the abundance and biomass of zooplankton and water quality parameters in Kukkarahalli Lake of Mysore, India. J. Environ. Biol., 32(5): 551 - 557.

Koste, W. and Shiel, R. J. (1986). Rotifera from Australian inland waters. I. Bdelloidea (rotifera: Digononta). Mar. Freshwater Res., 37: $765-792$.

Koste, W. and Shiel, R. J. (1987). Rotifera from Australian inland waters. II. Epiphanidae and Brachionidae (Rotifera: Monogononta). Invertebr. Syst., 1: $949-1021$.

Kulakov, D.; Makushenko, M. Y. and Vereshchagina, Y. A. (2018). Influence of Heated Waters Discharge on Zooplankton of Various Cooling Ponds of Nuclear Power Stations. Hydrobiol. J., 54(3): 60 - 74.

Mola, H. R. A. and Ahmed, N. A. M. (2015). Zooplankton Community Structure and Diversity Relative to Environmental Variables in the River Nile from Helwan to El-Qanater El-Khayria, Egypt. Int. J. Environ., 4(4): 140 - 150.

Montagud, D.; Soria, J. M.; Soria-Perpiñà, X.; Alfonso, T. and Vicente, E. (2019). A comparative study of four indexes based on zooplankton as trophic state indicators in reservoirs. Limnetica, 38(1): $291-302$.

Nakajima, R.; Rimachi, E. V.; Santos-Silva, E. N.; Calixto, L. S.; Leite, R. G.; Khen, A.; Yamane, T.; Mazeroll, A. I.; Inuma, J. C. and Utumi, E. Y. (2017). The density and biomass of mesozooplankton and ichthyoplankton in the Negro and the Amazon Rivers during the rainy season: the ecological importance of the confluence boundary. PeerJ, 5(5): $1-19$.

Pernet-Coudrier, B.; Qi, W.; Liu, H.; Muller, B. and Berg, M. (2012). Sources and pathways of nutrients in the semi-arid region of Beijing-Tianjin, China. Environ. Sci. Technol., 46(10): $5294-5301$.

Riccardi, N. (2010). Selectivity of plankton nets over mesozooplankton taxa: implications for abundance, biomass and diversity estimation. J. Limnol., 69(2): $287-296$.

Rodríguez, L. P.; Granata, A.; Guglielmo, L.; Minutoli, R.; Zagami, G. and Brugnano, C. (2013). Spring rotifer community structure in the Alcantara River (Sicily, Italy), using different mesh size nets: relation to environmental factors. EDP Sciences, 49: $287-300$.

Rzoska, J. (1976). Zooplankton of the Nile system. In: "The Nile, biology of an ancient river." Springer, pp. $333-343$.

Sala, O. E.; Chapin, F. S.; Armesto, J. J.; Berlow, E.; Bloomfield, J.; Dirzo, R.; Huber-Sanwald, E.; Huenneke, L. F.; Jackson, R. B. and Kinzig, A. (2000). Global biodiversity scenarios for the year 2100. Science, 287(5459): 1770 1774.

Seaby, R.; Henderson, P. and Prendergast, J. R. (2004). Community analysis package. Pisces Conservation Ltd: Lymington, UK.

Sellami, I.; Guermazi, W.; Hamza, A.; Aleya, L. and Ayadi, H. (2010). Seasonal dynamics of zooplankton community in four Mediterranean reservoirs in humid area (Beni Mtir: north of Tunisia) and semi arid area (Lakhmes, Nabhana and Sidi Saâd: center of Tunisia). J. Therm. Biol., 35(8): $392-400$.

Sosnovsky, A.; Rechencq, M.; Rennella, A. M.; Cantet, R. J. C. and Vigliano, P. H. (2016). Mesozooplankton (Crustacea: Copepoda and Cladocera) dynamics in a large, ultra-oligotrophic Andean lake. Pan-Am. J. Aquat. Sci., 11(3): 243 250. 
Ter Braak, C. and Smilauer, P. (2005). "Program CANOCO version 4.5." Biometrics-quantitative methods in the life and earth sciences. Plant Research International, University and Research Centre, Wageningen, The Netherlands.

Tseng, L. C.; Dahms, H. U.; Hung, J. J.; Chen, Q. C. and Hwang, J. S. (2011). Can different mesh sizes affect the results of copepod community studies? J. Exp. Mar. Biol. Ecol., 398(1-2): 47 - 55.

Tunowski, J. (2009). Zooplankton structure in heated lakes with differing thermal regimes and water retention. Arch. Pol. Fish., 17(4): 291 - 303.

Wetzel, R. G. and Likens, G. E. (2000). Limnological Analyses: $3^{\text {rd }}$ Edition. Springer-Verlag New York: New York.

Xiong, W.; Ni, P.; Chen, Y.; Gao, Y.; Shan, B. and Zhan, A. (2017). Zooplankton community structure along a pollution gradient at fine geographical scales in river ecosystems: the importance of species sorting over dispersal. Mol. Ecol., 26(16): $4351-4360$.

Yin, L.; Ji, Y.; Zhang, Y.; Chong, L. and Chen, L. (2018). Rotifer community structure and its response to environmental factors in the Backshore Wetland of Expo Garden, Shanghai. Aquac. Fish., 3(2): 90 - 97.

Zdanowski, B. (1988). Long-term and seasonal changes in the primary production and destruction in heated lakes near Konin (Poland). Ekol. Polska, 36(1-2): 121 -139 .

Zdanowski, B. and Prusik, S. (1994). Temperature-oxygen relations and chemical composition of water in heated Konin lakes. Arch. Pol. Fish., 2(2): $161-178$.

Zhang, Y.; Johnson, A. C.; Su, C.; Zhang, M.; Jürgens, M. D.; Shi, Y. and Lu, Y. (2017). Which persistent organic pollutants in the rivers of the Bohai Region of China represent the greatest risk to the local ecosystem? Chemosphere, 178: 11 -18 . 